\title{
Differences in Creative Thinking Ability in Fractional Material Between Contextual Learning Based on Learning Styles and Direct Learning in Grade 5th Elementary
}

\author{
Rospita Silaban ${ }^{1, *}$ Bornok Sinaga $^{2}$ Ramlan Silaban ${ }^{3}$
}

\author{
${ }^{1}$ Postgraduate Student at Medan State University, Indonesia \\ ${ }^{2,3}$ Postgraduate Lecturer at the State University of Medan, Indonesia \\ *Corresponding author. Email: rospitasilaban26@gmail.com
}

\begin{abstract}
The purpose of this study was to determine: (1) Is the ability of students to think creatively in the application of a learning style-based contextual learning model higher than direct learning, (2) How is the student's activity during contextual learning based on learning styles (3) What is the level of the teacher's ability to manage the classroom in application of contextual learning model based on learning styles, and (4) How is the process of student answers in the application of contextual learning model based on learning styles in class V SD Negeri 106161 Laut Dendang. This research is a quasi-experimental research. The population of this study were all grade 5th students of SD Negeri 106161 Laut Dendang which consisted of 3 parallel classes. Of all the grade 5th students, 2 classes were selected as the sample. The experimental class was treated with contextual learning based on learning styles and the control class was given direct learning treatment. The analysis technique used is descriptive analysis to describe student activities, the teacher's ability to manage learning, and the student answer process. Inferential data analysis was performed by analyzing covariance (ANACOVA). The results showed: (1) The ability of students to think creatively in the application of contextual learning based on learning styles was higher than direct learning (2) The level of active activity of students during the application of contextual learning based on learning styles met the ideal time tolerance (3) The ability of the teacher to manage the implementation of learning during Contextual learning based on learning styles is categorized as quite good (4) The process of completing students' answers by using contextual learning based on learning styles is higher than direct learning.
\end{abstract}

Keywords: Contextual Learning, Learning Styles, and Learning Outcomes.

\section{INTRODUCTION}

Developments that occur in global life which include the life of society, nation and state are inseparable from the development of science and technology. Meanwhile, the progress of science and technology cannot be separated from the role of education because through education everything can be understood. Therefore, the importance of education affects the development of science and technology in society, the more advanced the people in a country, the higher the mindset of the people.

The development of science and technology allows all parties to obtain information in abundance, quickly and easily through various sources and places in this world. Call it the internet which is one of the developments of technology.

Advances in science and technology bring change and development of society to be able to master information and knowledge. These advances require each individual to become a quality human being who has the ability to obtain, select, sort, manage, and follow up on information. These abilities require critical, systematic, logical, and creative thinking. Therefore, we need a field of science that can develop critical, systematic, logical, and creative thinking skills. One of the fields of science that can develop creative thinking skills is mathematics. 
Hasratuddin (2015:37) which states that mathematics is a product of human intellectual thinking.

Mathematics learning given at the low level stage of Elementary School (SD) aims to provide students with provisions for the future with the ability to think logically, analytically, systematically, creatively and actively, as well as the ability to work together. Soedjadi (2000:13) states that students in the elementary stage need to be equipped with these abilities because of the rapid development of modern technology at this time. The process of studying mathematics makes students able to solve problems in everyday life such as being able to count, being able to use calculators, computers and others.

Various indicators show that the quality of education, especially mathematics education, which automatically touches students' mathematics learning achievement starting from elementary school, middle school to university, has not significantly improved. Why this can happen, most likely there are internal problems that exist in students. Like the desire to learn mathematics they are less because they think mathematics is difficult to learn. besides that they have difficulty in answering questions because of their lack of thinking skills.

Thinking skills are the skills to manipulate data, facts and information to make behavioral decisions. Equating intelligence with thinking skills will lead to two detrimental conclusions in education, namely that we do not need to do anything more for students who have very high intelligence, because they are automatically good thinkers too, and there is nothing that can be done to students. students who do not have high intelligence, because they will never be good thinkers. (Tawil and Liliasari, 2013: 1-3).

According to the research results of Tetty Khairani Nasution, Edy Surya, Asmin, and Bornok Sinaga (2017) stated that: The results show the students in three categories in the indicator of creative thinking ability. Students in the low category of students. Only able to load indicators of fluency and flexibility. Student B is capable of loading smoothness and authenticity. Students in the medium category of students $\mathrm{C}$ is able to contain fluency, flexibility, and authenticity. Student D is capable of loading flexibility, authenticity, and detail. Students in the high category of students $\mathrm{E}$ is able to contain fluency, flexibility",

From the results of the study, it was explained that students were in the category of low students. Only able to load indicators of fluency and flexibility. Student B is able to load fluency and authenticity. Students in the medium category $\mathrm{C}$ students are able to contain fluency, flexibility, and originality. Student D is able to include flexibility, originality, and detail. Students in the high category of $\mathrm{E}$ students are able to contain fluency, flexibility.
The following table shows the average results of the initial diagnosis test scores for creative thinking skills of fifth grade students in pre-learning Mathematics at SD Negeri 106161 Laut Dendang.

Table 1. Average Value of the Diagnostic Test of Creative Thinking Skills of Students Prerequisite Material in Class V SDN 106161 Laut Dendang.

\begin{tabular}{|l|l|l|l|l|}
\hline \multirow{2}{*}{ Aspect } & \multicolumn{4}{|l|}{ Level Percentage } \\
\cline { 2 - 5 } & $\mathbf{1}$ & $\mathbf{2}$ & $\mathbf{3}$ & $\mathbf{4}$ \\
\hline Originality & $87,92 \%$ & $10,83 \%$ & $1,25 \%$ & 0 \\
\hline Fluency & $100 \%$ & 0 & 0 & 0 \\
\hline Flexibility & $96,66 \%$ & $2,08 \%$ & $0,84 \%$ & $0,42 \%$ \\
\hline Elaboration & $100 \%$ & 0 & 0 & 0 \\
\hline
\end{tabular}

Based on the data obtained in table 1, it shows that the results of the analysis of the pre-learning diagnostic test results for prerequisite materials in class V SD Negeri 106161 Laut Dendang, for the aspect of originality that reaches level 3 only $1.25 \%$ or in the low category. Based on this, the originality aspect has not been in accordance with the desired expectations. To improve student originality, teachers must be able to guide students in solving a problem in order to produce original ideas as their own thoughts.

The application of contextual learning can contribute to alternative solutions to mathematics learning problems, especially in improving students' mathematics learning achievement. In SD itself, the application of contextual learning in mathematics learning is possible because the mathematics topics taught in elementary schools are generally still largely connected to everyday life. In addition, according to Piaget in Slameto (2003:1213) suggests that elementary school students are in the formal operational stage, their thinking processes are not fully abstract, so they still need real objects in their learning.

Learning outcomes can be obtained from sharing experiences. Modeling is a learning process by exemplifying or demonstrating something as an example that can be imitated by students. Next is reflection, which in this process concludes the learning together. And the last is a real assessment, where the teacher gives an evaluation to students to test the extent to which students understand the material that has been studied

In contextual learning the teacher needs to understand the type of student learning, where the teacher must be able to adjust the stages of learning to the student's learning style. The teaching and learning process will be more enjoyable if it is able to utilize students' modalities in learning. The first step that must be known is to recognize one's modality as a learning style modality of converger, diverger, assimilator, and accommodator. 
Modality is the ability to receive the information obtained. Each individual has the ability of the four modalities, but most students show strengths and tendencies in one particular learning style compared to the other three.

\section{LITERATURE REVIEW HYPOTHESIS DEVELOPMENT}

AND

Hamalik (2003:57) states that the term mathematics comes from the Greek word "mathein" or "manthenein" which means to study. Meanwhile, in the Complete Indonesian Dictionary, Masykur (2007:42) states that mathematics is the science of numbers, the relationship between numbers, and operational procedures used in solving problems about numbers.

Susanto (2014: 185) states that mathematics is a scientific discipline that can improve the ability to think, argue and even contribute to helping solve problems in everyday life, as well as providing support in the development of science and technology.

Therefore, can be concluded that learning mathematics can be interpreted as one of the very important subjects to be mastered from an early age because in everyday life what humans do cannot be separated from mathematical activities.

The learning model is a way of designing the implementation of learning. Through the learning model, there will be efforts to create a climate and service for the diverse abilities, potentials, interests, talents and needs of students so that interactions occur between teachers and students or between students. In a learning model, there are usually stages or steps (syntax) that are relatively fixed and definite to present the subject matter sequentially.

Dimyati and Mudjiono (2016: 297) state that learning is a teacher activity programmed in instructional design, to make students learn actively which emphasizes the provision of learning resources. The characteristics of learning are to support the student learning process, the interaction between individuals and learning resources that have interrelated components of objectives, materials, processes and evaluations.

Trianto (2015:107) states that the contextual learning model is a learning concept that helps teachers relate the material they teach to real situations experienced by students and encourages students to form relationships between their knowledge and its application in their daily lives.

Ngalimun (2016: 230) states that the contextual learning model is a learning concept that starts from oral questions and answers or presentations related to real situations experienced by students so that the benefits of the material presented will be more tangible.
Rusman (2013: 332) states that the contextual learning model is a learning concept that assumes that children will learn better if they experience what they learn for themselves, so it is not only limited to knowing the theory that is being learned. A similar opinion by Hamdayana (2016:136) states that the contextual learning model is a learning concept that can assist teachers in teaching by linking the material discussed to real situations in students' lives.

Shoimin (2014:41) states that the contextual learning model is a comprehensive learning process, which aims to motivate students to understand the meaning of the material being studied by relating it to everyday life so that students have knowledge and skills that can be applied from one problem to another. other.

Thinking skills are relatively specific skills in thinking about something that someone needs to understand information in the form of ideas, concepts, theories and so on. According to Liliasari's opinion (in Tawil and Liliasari, 2013: 59) that thinking skills are very decisive in building personality and action patterns in the life of every human being. One of the thinking skills that must be developed is creative thinking skills.

According to Tawil and Liliasari (2013: 59) that creative thinking is characterized by feeling the difficulty of the problem of information gaps, missing elements and disharmony, defining the problem clearly, getting new ideas, making assumptions and possible improvements, re-testing or redefining problems and finally communicate the results.

According to Hassoubah (2004:20) that the ability to think creatively is the ability to generate new ideas or ways of producing a product. In general, creative thinking is triggered by challenging problems. Krulik in Siswono (2005:2) suggests that in understanding and planning problem solving, an adequate creative thinking ability of students is needed, because this ability is a highlevel thinking ability after basic and critical thinking.

The research hypothesis is the influence of contextual learning models based on learning styles on the creative thinking skills of fifth grade elementary school students.

\section{RESEARCH METHODS}

This research is a quasi-experimental study (quasiexperimental) with the aim of seeing whether there is an effect of applying a contextual learning model based on learning styles on creative thinking skills. This research is a quasi-experimental research because students' conditions cannot be fully controlled, such as student preparation before studying at school, additional tutoring outside school hours, student relationships with parents, student relationships with their environment, and so on.

This research was conducted at SD Negeri 106161 Laut Dendang for the Academic Year 2020/2021. This research was carried out according to the schedule for 
entering the mathematics subject in question and the teacher who taught in giving treatment was the mathematics teacher in class V SD Negeri 106161 Laut Dendang. The population in this study were all students of class V SD Negeri 106161 Laut Dendang which amounts to 80 students divided into 3 classes, namely, class V-A as many as 28 students, class V-B as many as 28 students and $\mathrm{V}-\mathrm{C}$ as many as 24 students.

In connection with the formulation of the problem in this study, descriptive statistical analysis was carried out in analyzing data to analyze the process of answers given by students and inferential statistical analysis was carried out to analyze whether students' creative thinking abilities in the application of contextual learning models based on learning styles were higher than direct learning.

\section{RESULTS AND DISCUSSION}

The students' creative thinking ability test was conducted twice, namely the initial ability test and final ability test. The initial and final tests were attended by 28 students in each class so that in the data analysis the subjects of this study were 28 students, namely students who took the initial ability test and the final ability test.

To test the hypothesis, it can be seen from the calculation results of the creative thinking ability of the experimental class and control class using the SPSS program, which is briefly described in the following table:

Table 2. Covariance Analysis for Complete Design Creative Thinking Ability Tests of Between-Subjects Effects

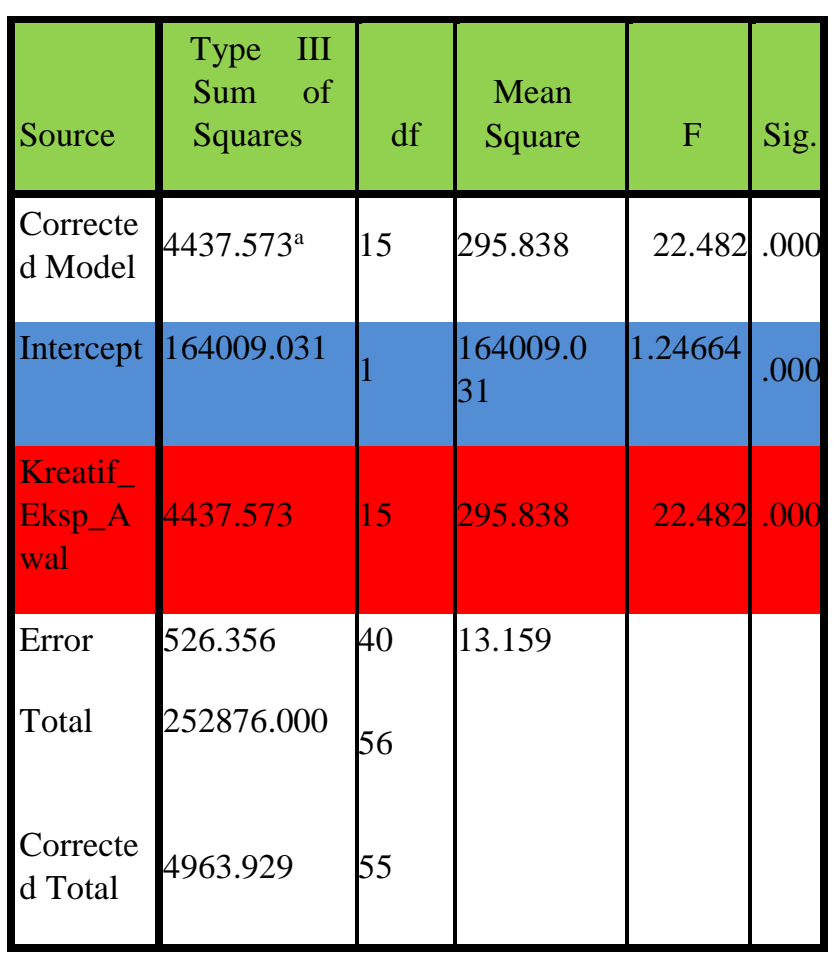

a. R Squared $=, 894$ (Adjusted R Squared $=, 854$ )
For the ability to think creatively, the value of Sig. 0.000 . Because Sig. < that is $0.000<0.05$, it can be concluded that at the $95 \%$ confidence level, the final ability test results are influenced by students' initial ability tests before being given a learning model. Therefore, the error can be corrected by the initial ability test scores as covariates/variants.

The regression model that has been obtained for the creative thinking ability of the experimental class is $\mathrm{YE}=10,683+1,018 \mathrm{XE}$ and the regression equation for the control class is $\mathrm{YK}=1,513+1,084 \mathrm{XK}$. Furthermore, because the two regressions for both classes are homogeneous and the linear regression equation constant for the experimental class creative thinking ability is 10,683 which is greater than the control class linear regression equation constant, which is 1.513 , geometrically the regression line for the experimental class is above the control class regression line.

This indicates that there is a significant difference, and the hypothesis above is that there is a difference in height of the two regression lines which is influenced by the regression constant. The height of the regression line describes student learning outcomes, namely when $\mathrm{X}=0$ then the regression equation for the creative thinking ability of the experimental class is $\mathrm{Y}=1.018$ and the regression equation for the control class is $\mathrm{Y}=1.084$. It means that it can be concluded that the application of contextual learning model based on learning style has an effect on students' creative thinking ability.

The percentage of listening activities/paying attention to teacher/friend explanations of $25.13 \%$ is the third largest proportion of time with the activity tolerance limit set at. This shows that students have the awareness to pay attention to explanations from both the teacher and their friends. The proportion of these activities is still within the tolerance limits for achieving the effectiveness of listening and paying attention to the explanations of teachers and friends when implementing learning in the classroom.

By looking at the overall average score and the description of the teacher's ability to manage learning, it can be concluded that the teacher's ability to manage learning is in a fairly good category.

Not many experimental class students were able to complete each item by meeting the neat category, sequential steps and correct completion, but there were also those who met the neat category, sequential steps and incorrect completion. Students solve problems with neat categories, sequential steps and correct completion in the control class using less direct learning than in the experimental class using contextual learning based on learning styles.

In the experimental class using contextual learning based on learning styles, the results of the final creative thinking ability test have a maximum score of 82 , a 
minimum score of 50, with a mean of 70.00. The level of creative thinking ability in the experimental class got a B- of 1 student, B as many as 3 students, B+ as many as 5 students, A- as many as 9 students, and A as many as 10 students.

Contextual learning, which is influenced by the philosophy of constructivism, is a learning concept that links the material taught to students' real world situations, and encourages students to make connections between the knowledge they have and its application in their daily lives. In the application of contextual learning, it involves seven main components, namely constructivism (constructivism), asking (questioning), finding (inquiry), learning community (learning community), modeling (modeling), and actual assessment (authentic assessment).

Hanik (2010:29) asserts that constructivism is one of the developments of the latest learning model that prioritizes student activities in every educational interaction to be able to explore and find their own knowledge. Constructivism is a philosophy of knowledge that emphasizes that our knowledge is our own construction, not an imitation of reality, not a picture of the world of reality that exists.

Nurhidayati (2017:1) argues that knowledge is always the result of cognitive construction from reality that occurs through a series of one's activities. According to Piaget (in Ibda, 2015:30) suggests that the cognitive structure of how children develop the concept of the world around them. Piaget's theory is often called genetic epistemology (genetic epistemology) because this theory seeks to trace the development of intellectual abilities, that genetics refers to developmental growth, not biological inheritance (heredity). Children are born with several sensory-motor schemata, which provide the framework for the child's initial interactions with the environment.

Based on the results of the students' creative thinking ability test, it was found that there was a significant difference and a tendency for higher results between creative thinking skills in the experimental class using contextual learning based on learning styles.

\section{CONCLUSION}

Based on the analysis of research data and discussion of research on the application of contextual learning based on learning styles by emphasizing students' creative thinking skills, the researchers put forward the following conclusions:

1. There is an effect of applying contextual learning model based on learning style to students' creative thinking ability on inner fraction material which is better than students' creative thinking ability in applying direct learning.
2. The creative thinking ability of students with convergent and accommodator learning styles is better than the creative thinking abilities of students with divergent and assimilator learning styles.

3. The level of active student activity during the application of contextual learning based on learning styles meets the ideal time tolerance.

4. The ability of teachers to manage the implementation of learning during contextual learning based on learning styles is categorized as quite good.

5. The process of completing student answers in the application of contextual learning models based on learning styles is better than the process of completing student answers in the application of direct learning. This is indicated by the students' answers in completing the creative thinking ability test higher in the application of contextual learning models based on learning styles than students' answers in completing the creative thinking ability test in the application of direct learning.

\section{REFERENCES}

[1] Alma, Buchari. 2015. Kewirausahaan. Bandung: Alfabeta.

[2] Anas, Sudijono. 2012. Pengantar Evaluasi Pendidikan. Jakarta: Raja Grafindo Persada.

[3] Aqib, Zainal. 2016. Model-Model, Media, dan Strategi Pembelajaran Kontekstual (Inovatif). Bandung: Yrama Widya.

[4] Arends, Richard. 2015. Learning to Teach. Penerjemah : Helly Prajitno dan Sri Mulyani. New York: McGraw Hill Company.

[5] Arikunto, S. 2009. Dasar-dasar Evaluasi Pendidikan (Edisi Revisi). Jakarta: Bumi Aksara.

[6] Birgili, Bengi. 2015. Creative and Critical Thinking Skills in Problem-based Learning Environments. Journal of Gifted Education and Creativity, 2(2), 71 80.

[7] BSNP. 2006. Kurikulum Tingkat Satuan Pendidikan Standar Kompetensi Mata Pelajaran Matematika SMP dan MTs. Jakarta: Badan Standar Nasional Pendidikan.

[8] Depdiknas. 2002. Ringkasan Kegiatan Belajar Mengajar. Jakarta: Depdiknas.

[9] Depdiknas. 2003. Undang-Undang RI No.20 Tahun 2003.Tentang Sistem Pendidikan Nasional. 
[10] Depdiknas. 2005. Panduan Pengembangan Model Pembelajaran Berbasis Kompetensi.Jakarta: Direktorat PPTK dan KPT Dirjen Dikti.

[11] Deporter B \& Hernacki M. 2016. Quantum Learning.Bandung. Mizan Pustaka.

[12] Dhea H., dkk. 2016. Penerapan Model Contextual Teaching and Learning Meningkatkan Hasil Belajar Siswa. (Sumedang).

[13] Dimyati, Mudjiono. 2016. Belajar dan Pembelajaran. Jakarta: Rineka Cipta.

[14] Erik, Santoso. 2017. Penggunaan Model Pembelajaran Kontekstual Untuk Meningkatkan Kemampuan Pemahaman Matematika Siswa Sekolah Dasar (Majalengka).

[15] Erman, Suherman. 2001. Strategi Pembelajaran Matematika Kontemporer Bandung: Universitas Pendidikan Indonesia.

[16] Gunawan, Adi. 2006. Genius Learning Strategi. Jakarta: Pustaka Utama Gramedia

[17] Hadijah. 2015. Media Pembelajaran Anak Usia Dini. Medan: Perdana Publishing.

[18] Halim, Abdul dkk. 2008. Mathematical Intelligence Cara Cerdas Melatih Otak dan Menanggulangi Kesulitan Belajar. Jogyakarta: Ar-Ruzz Media.

[19] Hamalik, Oemar. 2003. Proses Belajar Mengajar. Jakarta: Bumi Aksara.

[20] Hamdayama, Jumanta. 2016. Metodologi Pengajaran. Jakarta: Bumi Aksara

[21] Hasratuddin. 2015. Mengapa Harus Belajar Matematika. Perdana Publishing: Medan.

[22] Hawkar, Akram. 2014. Learning styles and Their Relation To Teaching Style. International Journal of Language and Linguistics. Vol. 2, No. 3, 2014, pp. 241- Diakses pada tanggal 12 februari 2020

[23] Hudoyo, H. 1998. Mengajar Belajar Matematika. Jakarta: Depdikbud.

[24] Istarani. 2012. 58 Model Pembelajaran Inovatif. Medan: Media Persada.

[25] Jamalia. 2018. Model CTL Untul Meningkatkan Hasil Belajar Matematika Kedemangan. Kademangan: Universitas Muria Kudus.

[26] Joyce. B dan weil. M. 2015. Model of Teaching, Foreword by James worlfsixth Edition Amerika.

[27] Kamsiyati, Siti. 2018. Pengaruh Model Pembelajaran Kontekstual Terhadap Hasil Belajar Matematika. Surakarta: Tesis. Universitas sebelas maret)
[28] Kistan, Agus. 2018. Pengaruh Model Pembelajaran Contextual Teaching and Learning. Jakarta: Raja Grafinda.

[29] Kurniati dkk. 2015. Mathematical Critical Thinking ability Through Contextual Teaching and Learning Approach. IndoMS-JME, Volume 6, No. 1, January 2015, pp. 53-62. Diakses pada tanggal 12 februari 2020 .

[30] Lestari, Ade. 2012. Penerapan Strategi Pembelajaran Matematika berbasis Gaya Belajar VAK (Visual, Auditori, Kinestetik). Padang. Tesis. UNP.

[31] Momon, Sudarma. 2013. Mengembangkan Keterampilan Berfikir Kreatif. Jakarta: RajaGrafindo Persada.

[32] Munandar, U. 2012. Pengembangan Kreativitas Anak Berbakat. Jakarta: Rineka Cipta.

[33] Nasution. 2013. Berbagai Pendekatan dalam Proses Belajar Mengajar. Jakarta: Bumi Aksara.

[34] Netter, J. 1974. Applied Linier Statistical Model. Illions: Richard D. Erwin, INC.

[35] Ngalimun. 2016. Strategi dan Model Pembelajaran. Yogyakarta: Aswaja Pressindo

[36] Priyatni, Hamidah, dan Adi. 2017. Pembelajaran Reflektif. Tangerang: Tira Smart.

[37] Ria, Hardiyati. 2014. Pengaruh Pendekatan Realistic Mathematics Education Terhadap Kemampuan Berpikir Kreatif Siswa. Jakarta: Grapindo Persada

[38] Rusman. 2013. Pembelajaran

Model-Model Profesionalisme Guru Edisi Kedua. Jakrta: RajaGrafindo Persada.

[39] Sagala, S. 2016. Konsep dan Makna Pembelajaran. Bandung: Alfabeta.

[40] Sanjaya, W. 2008. Strategi Pembelajaran. Bandung: Kencana Prenada Media Group.

[41] Setyowati, Renny. 2017. Peningkatan Kreativitas Siswa Kelas IV SD Melalui Model Pembelajaran Contextual Teaching And Learning (CTL). Tesis. Universitas Kristen Satya Wacana.

[42] Shoimin, Aris. 2014. 68 Model Pembelajaran Inovatif Dalam Kurikulum 2013.

[43] Sinaga, Bornok, dkk. 2018. Analysis Difficulty of Mathematical Creative Thinking Ability Reviewed From Learning Styles Through Problem Based Learning. Advances in Social Sciences Research Journal - Vol.5, No.10 Publication Date: Oct. 25, 2018.p.38. 
[44] Sinaga, Bornok. 2007. Pengembangan Model Pembelajaran Matematika Berdasarkan Masalah Berbasis Budaya Batak. Disertasi tidak diterbitkan. Surabaya: PPs UNESA.

[45] Siswanto, Joko. 2012. Pengaruh Penggunaan Model Pembelajaran Kontekstual Dengan Media AudioVisual Terhadap Kemampuan Berpikir Kritis Dan Kreatif Siswa (Semarang: Tesis. IKIP PGRI Semarang).

[46] Soedjadi. 2000. Kiat Pendidikan Matematika di Indonesia. Jakarta: Direktorat Jendral Pendidikan Tinggi Departemen Pendidikan Nasional.

[47] Soejadi, R. 2005. Kiat Pendidikan Matamatika Di Indonesia, Direktorat Jendral Pendidikan Tinggi Departemen Pendidikan Nasional,Jakarta.

[48] Sriyanto. 2007. Strategi Sukses Menguasai Matematika. Yogyakarta: Indonesia Cerdas.

[49] Sudjana. 2005. Metoda Statistika. Bandung: Tarsito.

[50] Suprihatiningrum, Jamil. 2013. Strategi Pembelajaran Teori dan Aplikasi.

[51] Surip, Muhammad. 2013. Berpikir Kritis analisis Kajian filsafat Ilmu. Jakarta. Halaman Moeka Publishing.

[52] Susanto, Ahmad. 2014. Teori Belajar dan Pembelajaran di Sekolah Dasar. Jakarta: Kencana Prenada Media Group.

[53] Takdir, Mohamad Hahi. Pembelajaran Discovery Strategi dan Mental Vocational Skill. hlm. 191.

[54] Tawil, M. \& Liliasari. 2013. Berpikir Kompleks dan Ilmplementasinya Dalam Pembelajaran IPA. Makasar: Badan Penerbit UNM.

[55] Trianto, 2014. Model-Model Pembelajaran Inovatif Berorientasi Konstruktivistik, Penerbit Prestasi Pustaka, Jakarta.

[56] Trianto. 2015. Mendesain Model Pembelajaran Inovatif, Progresif, dan Kontekstual. Jakarta: Prenada Media Group

[57] Utami, Munandar. 1999. Mengembangkan Bakat dan Kreatifitas Anak Sekolah.

[58] Widha, Nur dkk. 2018. Meningkatkan Kemampuan Berpikir Kritis Melalui CTL. Yogyakarta: Universitas Alma Ata.

[59] Wijaya, A. 2012. Pendidikan Matematika Realistik: Suatu Alternatif Pendekatan Pembelajaran Matematika. Yogyakarta: Graha Ilmu

[60] Winarti. 2015. Contextual Teaching And Learning Untuk Meningkatkan Kemampuan Berpikir Kreatif Siswa. Yogyakarta: UIN Sunan Kalijaga. 